\title{
Efficacy of Some Botanical Extracts on the Control of Late Blight Disease in Experimental Potato Field
}

\author{
Shafiqul Islam1, Md. Abul Kalam Azad1*, Md. Rashidul Islam², Mst. Samia Sultana1, \\ Jesmin Ara Khatun', Md. Huzzatul Islam² \\ ${ }^{1}$ Botanical Pesticides and Environmental Microbiology Lab, Institute of Environmental Science, University of Rajshahi, \\ Rajshahi, Bangladesh \\ ${ }^{2}$ Department of Plant Pathology, Bangladesh Agricultural University, Mymensingh, Bangladesh \\ Email: ^akazad_ies@yahoo.com
}

How to cite this paper: Islam, S., Azad, M.A.K., Islam, M.R., Sultana, M.S., Khatun, J.A. and Islam, M.H. (2021) Efficacy of Some Botanical Extracts on the Control of Late Blight Disease in Experimental Potato Field. Advances in Bioscience and Biotechnology, 12, 426-435.

https://doi.org/10.4236/abb.2021.1212027

Received: October 21, 2021

Accepted: December 10, 2021

Published: December 13, 2021

Copyright $\odot 2021$ by author(s) and Scientific Research Publishing Inc. This work is licensed under the Creative Commons Attribution International License (CC BY 4.0).

http://creativecommons.org/licenses/by/4.0/

\begin{abstract}
Late blight caused by Phytophthora infestans (Mont.) De Bary is the most devastating disease of potato. This study was carried out to evaluate the efficacy of ten botanical extracts against the late blight disease incidence and severity in experimental potato field at University of Rajshahi, Bangladesh during 2019-2020. Crude aqueous extract of leaves of Syzygium cumini, Psidium guajava, Eucalyptus globusus, Carica papaya and Lawsonia inermis, fruits of Terminalia bellirica, T. chebula and Piper nigrum; flower buds of Syzygium aromaticum and cloves of Allium sativum were used at 5\% (w/v) concentration for evaluation. Out of ten botanicals, Syzygium cumini leaves extract was found most effective in controlling the late blight disease incidence and severity up to 66 DAS (days after sowing) and increased the potato yield by 71.29\% compare to untreated control. The efficacy of Lawsonia inermis extract against late blight disease was found promising and increased the potato yield by $48.51 \%$. Other four botanical extracts (Terminalia chebula, Piper $n i-$ grum, Syzygium aromaticum and Carica papaya) showed moderate efficacy against the incidence and severity of late blight disease, and increased 30\% more potato yield compare to control. These results suggest that botanical extract of Syzygium cumini has a great potential as an alternative of chemical fungicides to control the late blight disease of potato in eco-friendly way.
\end{abstract}

\section{Keywords}

Botanical Extract, Late Blight Disease, Potato, Phytophthora infestans,

Experimental Field 


\section{Introduction}

Potato is the third most important food crop in the world after rice and wheat in terms of human consumption [1]. Potato is the staple food in many countries. It is the cheapest source of carbohydrate and it contains a good amount of vitamin B6 and C as well as some minerals [2] [3]. A significant amount of potato used in processing industries such as production of alcohol, glucose, dextrin and citric acid for textile and paper industries, inks, dyes, soap and leather as their raw materials [4]. According to Azad, potato is the raw material for production of eco-friendly fuel like bio-ethanol [5]. In Bangladesh, potato is the second most important crop after the paddy. Among the exportable agricultural commodities of Bangladesh, potato is in second position [6].

Potatoes suffer from various diseases such as late blight, early blight, black scurf, stem rot, scab, hallow heart, black heart, soft rot, common rust, bacterial wilt, etc. Among the diseases, late blight and early blight are most common diseases of potato. Late Blight caused by an oomycete Phytophthora infestans (Mont.) De Bary is the most devastating disease of potato [7] [8]. This disease is well known for the historical Irish Potato Famine 1840s [9] [10]. Early blight is caused by a true fungus Alternaria solani. The severity of both diseases is dependent on weather conditions and susceptibility of the crop. Cool and moist weather favor late blight of potato while early blight develops under drier conditions. If uncontrolled in favorable weather, late blight can completely destroy a field within a very short time and cause for yield loss up to 50\% - 70\% [11]. Usually early blight is not much destructive as late blight. In Bangladesh, late blight occurs every year in potato field with varying degrees of severity [12].

Usually chemical fungicides are used to control the late blight disease of potato. Most common fungicides are metalaxyl, mancozeb, chlorothalonil, cymoxanil, dimethomorph, fenamidone and propineb used to manage the late blight disease. But the indiscriminate use of fungicides enhances the development of resistance in $P$. infestans, increases the production cost but more important being it is harmful to the environment as well as human health. Excessive and injudicious use of these fungicides have been degrading our ecosystem and causing many diseases to human such as neurological, psychological dysfunctions, infertility, and cancer and kidney disorders [13]. Therefore, an alternative eco-friendly way of controlling late blight of potato is most desired in the world. Among the several available alternative materials, botanical extracts are the safer alternative to the chemical fungicides. Botanical extracts possess several antimicrobial metabolites having less toxicity to human and environment. In recent years, use of plant origin products in the management of plant diseases has gained popularity around the world [14]. Plant based fungicides are selective, biodegradable, less toxic and effective compared to synthetic fungicides [15]. Botanical fungicides can serve as suitable substitutes to synthetic fungicides [16] because of their eco-friendly nature and low cost [17].

Therefore, the objectives of the present study were to assess the efficacy of some Bangladeshi botanicals to control the incidence and severity of late blight 
disease of potato in experimental field.

\section{Materials and Methods}

\subsection{Experimental Site and Plot Preparation}

A field experiment on potato was carried out in the Botanical Pesticide Experimental Field of Institute of Environmental Science, University of Rajshahi, Bangladesh during November 2019 to February 2020. The experiment area is located at $24.37^{\circ} \mathrm{N}$ latitude and $88.7^{\circ} \mathrm{E}$ longitude at an altitude of 21 meters above sea level. The land was firstly ploughed several times with power tiller and grass and weeds are removed. A required amount of Triple Super Phosphate (TSP), Muriate of Potash (MP) and Urea fertilizers were applied in the experimental field and the field was irrigated twice.

\subsection{Collection of Botanicals}

Botanicals were screened considering the odor, anti-fungal activity and phyto-toxicity. Previous studies and ethno botanical knowledge were also considered to select the plants. Most of the plant materials were collected from Rajshahi University campus and some were purchased from local market. Ten plant materials such as leaves of Indian blackberry (Syzygium cumini), Guava ( $P_{s i-}$ dium guajava), Eucalyptus (Eucalyptus globusus), Papaya (Carica papaya) and Henna (Lawsonia inermis); fruits of Bohera (Terminalia bellirica), Horitoki ( $T$. chebula) and Black pepper (Piper nigrum), flower buds of Clove tree (Syzygium aromaticum) and cloves of Garlic (Allium sativum) were evaluated against the late blight disease of potato under field conditions.

\subsection{Preparation of Botanical Extracts}

Plant parts were washed through running tap water 2 - 3 times and dried under shed for $2 / 3$ weeks. Air dried leaves were grinded with the help of electric grinder to make fine powder [18]. For the preparation of $5 \%$ aqueous extract (w/v), 50 $\mathrm{g}$ of each fine powder was dissolved separately in $1000 \mathrm{ml}$ of distilled water in container. Garlic bulbs were cut into small pieces and blended by blender. About $50 \mathrm{~g}$ of blended garlic dissolved in $1000 \mathrm{ml}$ of distilled water. The containers were stored at room temperature for 72 hours with gentle shaking ( 2 - 3 times) everyday. Then aqueous extract was filtered through three-layer cheesecloth to collect the final extract for spray. The extracts were stored in bottle and preserve in the refrigerator for future use.

\subsection{Experimental Design and Treatments}

Experiment was laid out under field conditions in a randomized complete block design (RCBD) with three replications. The distance between the block was 0.75 $\mathrm{m}$ and between the plots was $0.5 \mathrm{~m}$, the unit plot size was $1 \mathrm{~m} \times 1.5 \mathrm{~m}$. Twelve treatments were used in this study including two controls (one untreated and one chemical treated) and ten plant extracts (Table 1). 
Table 1. Description of treatments.

\begin{tabular}{cc}
\hline Treatment & Concentration \\
\hline T0-Untreated Control (Water) & - \\
T1-Chemical Treated (Fungicide-Chlorothalonil) & $1.5 \mathrm{ml} / \mathrm{l}$ \\
T2-Syzygium cumini & $5 \%(\mathrm{w} / \mathrm{v})$ \\
T3-Psidium guajava & $5 \%(\mathrm{w} / \mathrm{v})$ \\
T4-Eucalyptus globusus & $5 \%(\mathrm{w} / \mathrm{v})$ \\
T5- Allium sativum & $5 \%(\mathrm{w} / \mathrm{v})$ \\
T6- Terminalia bellirica & $5 \%(\mathrm{w} / \mathrm{v})$ \\
T7- Terminalia chebula & $5 \%(\mathrm{w} / \mathrm{v})$ \\
T8-Piper nigrum & $5 \%(\mathrm{w} / \mathrm{v})$ \\
T9-Syzygium aromaticum & $5 \%(\mathrm{w} / \mathrm{v})$ \\
T10-Lawsonia inermis & $5 \%(\mathrm{w} / \mathrm{v})$ \\
T11-Carica papaya & $5 \%(\mathrm{w} / \mathrm{v})$ \\
\hline
\end{tabular}

\subsection{Spraying of Botanical Extract and Data Collection}

Prepared botanical extracts were sprayed in the field with a hand sprayer to potato leaves twice a week, started at 30 Days after sowing (DAS). Data on disease incidence and severity was collected on 50,58, 66 and 73 DAS. Data on yield was collected after harvesting.

\subsection{Disease Assessment and Yield Calculation}

Disease was assessed in terms of percent disease incidence and percent disease severity. Collected data were calculated by using the formula [19] below:

$$
\text { Disease incidence }(\%)=\frac{\text { No. of diseased plants }}{\text { Total no. of plants observed }} \times 100
$$

Disease severity was determined by observing the disease symptoms on leaves of potato. The blight $(\%)$ of leaves was calculated under the following scale [20] in Table 2.

After harvesting total tuber yield (kg/plot) was recorded and percent yield increase over control was calculated through following formula [21]:

$$
\text { Yield increase }(\%)=\frac{\text { Treatment yield }- \text { Control yield }}{\text { control yield }} \times 100
$$

\subsection{Data Analysis}

Data analysis was done using one way ANOVA $(\mathrm{P} \leq 0.05)$ followed by Duncan's Multiple Range Test (DMRT) to identify the significant differences between the treatments by software SPSS (V20).

\section{Results}

The late blight symptoms in potato field were observed regularly and disease in- 
cidence (DI) and disease severity were determined on counting number of late blight infected plants and blighted portions on leaves. The first blight symptom was observed on T0 and T3 treatments at 48 days after sowing (DAS). All the treatments except T1 (Fungicide) were infected by late blight disease at 58 DAS. At this stage, the highest $(23.33 \pm 1.93 \mathrm{~b})$ disease incidence was observed in $\mathrm{T} 3$ and lowest ( $1.11 \pm 1.11 \mathrm{de}$ ) incidence in T2 (Table 3). Out of ten botanicals, the treatment $\mathrm{T} 2$ showed the best efficacy to control the late blight diseases at both 66 and 73 DAS. Other botanical treatments showed good efficacy against late blight incidence of potato up to 58 DAS except T3 and T4 (Table 3). At 73 DAS only $\mathrm{T} 2$ and T10 showed better efficacy over untreated control (water). The rest of the botanicals were statistically similar to untreated control at 73 DAS considering disease incidence (Table 3).

Table 2. Late blight disease severity scale.

\begin{tabular}{cc}
\hline Disease Severity Scale & Description of Scale \\
\hline 0 & No disease observed. \\
$0.1 \%$ & First sporulating lesion in the plot. \\
$1.0 \%$ & General light infection. About 5 - 10 lesions/plant. \\
$5.0 \%$ & About 50 lesions/plant; 1 in 10 leaflets affected. \\
$25 \%$ & Nearly every leaflet infected but plants retain normal form; plants may smell of blight. \\
$50 \%$ & Field looks green although every plant is affected. \\
$75 \%$ & About $75 \%$ of the leaf area destroyed; field appears neither predominantly green nor brown. \\
$95 \%$ & Only a few leaves on plants, but stems are green. \\
$100 \%$ & All leaves dead, stems dead or dying.
\end{tabular}

Table 3. Efficacy of plant extracts against late blight disease incidence (DI) of potato at different days after sowing (DAS).

\begin{tabular}{ccccc}
\hline Treatment & \% DI at DAS 50 & \% DI at DAS 58 & \% DI at DAS 66 & \% DI at DAS 73 \\
\hline T0-Untreated control (Water) & $3.33 \pm 1.93 \mathrm{a}$ & $46.67 \pm 1.93 \mathrm{a}$ & $100.00 \pm 0.00 \mathrm{a}$ & $100.00 \pm 0.00$ \\
T1-Positive control (Fungicide) & $0.00 \pm 0.00 \mathrm{~b}$ & $0.00 \pm 00 \mathrm{e}$ & $12.22 \pm 2.22 \mathrm{f}$ & $56.67 \pm 3.85 \mathrm{c}$ \\
T2-Syzygium cumini & $0.00 \pm 0.00 \mathrm{~b}$ & $1.11 \pm 1.11 \mathrm{de}$ & $53.33 \pm 1.93 \mathrm{e}$ & $93.33 \pm 3.85 \mathrm{~b}$ \\
T3-Psidium guajava & $1.11 \pm 1.11 \mathrm{~b}$ & $23.33 \pm 1.93 \mathrm{~b}$ & $100.00 \pm 00 \mathrm{a}$ & $100.00 \pm 0.00 \mathrm{a}$ \\
T4-Eucalyptus globusus & $0.00 \pm 0.00 \mathrm{~b}$ & $22.22 \pm 2.94 \mathrm{~b}$ & $98.89 \pm 1.11 \mathrm{a}$ & $100.00 \pm 0.00 \mathrm{a}$ \\
T5- Allium sativum & $0.00 \pm 0.00 \mathrm{~b}$ & $14.45 \pm 4.00 \mathrm{c}$ & $80.00 \pm 3.33 \mathrm{~d}$ & $100.00 \pm 0.00 \mathrm{a}$ \\
T6- Terminalia bellirica & $0.00 \pm 0.00 \mathrm{~b}$ & $7.78 \pm 2.94 \mathrm{~d}$ & $97.78 \pm 2.22 \mathrm{ab}$ & $100.00 \pm 0.00 \mathrm{a}$ \\
T7- Terminalia chebula & $0.00 \pm 0.00 \mathrm{~b}$ & $4.44 \pm 1.11 \mathrm{de}$ & $81.11 \pm 1.11 \mathrm{~d}$ & $100.00 \pm 0.00 \mathrm{a}$ \\
T8-Piper nigrum & $0.00 \pm 0.00 \mathrm{~b}$ & $6.67 \pm 1.93 \mathrm{de}$ & $94.44 \pm 2.94 \mathrm{abc}$ & $100.00 \pm 0.00 \mathrm{a}$ \\
T9-Syzygium aromaticum & $0.00 \pm 0.00 \mathrm{~b}$ & $5.56 \pm 1.11 \mathrm{de}$ & $91.11 \pm 2.22 \mathrm{bc}$ & $100.00 \pm 0.00 \mathrm{a}$ \\
T10-Lawsonia inermis & $0.00 \pm 0.00 \mathrm{~b}$ & $3.33 \pm 0.00 \mathrm{de}$ & $80.00 \pm 3.33 \mathrm{~d}$ & $94.45 \pm 4.00 \mathrm{ab}$ \\
T11-Carica papaya & $0.00 \pm 0.00 \mathrm{~b}$ & $6.67 \pm 1.93 \mathrm{de}$ & $88.89 \pm 2.94 \mathrm{c}$ & $100.00 \pm 0.00 \mathrm{a}$ \\
\hline
\end{tabular}


In case of severity (\%) of late blight disease, T2 showed the best efficacy among the botanical extracts (Table 4). The treatments T2, T9, T10 and T11 controlled the severity of late blight disease as good as T1 (fungicide) up to 58 DAS (Table 4). On 66 DAS, the highest disease severity $(65.17 \pm 4.21 \mathrm{a})$ was observed in T0 (untreated control). At the same period, second highest $(50.83 \pm 3.33 \mathrm{~b})$ and lowest $(21.50 \pm 0.00 \mathrm{e})$ late blight disease severity were observed in T4 and T2, respectively (Table 4). The treatments T7-T11 also showed considerable inhibition of disease severity over untreated control (Table 4) at 66 DAS. Data of 73 DAS revealed that all the botanical treatments except T2 statically similar to T0 (untreated control) and have no considerable efficacy on disease severity of late blight of potato.

The result of potato yield is shown in Table 5. After harvesting, yield per plot was measured and percent yield increase over untreated control was estimated. The highest yield $(26.33 \mathrm{mt} / \mathrm{ha})$ was observed in $\mathrm{T} 1$ (Fungicide) treatment (Table 5). Out of ten botanical extracts, the highest $(11.51 \mathrm{mt} / \mathrm{ha})$ and lowest (7.53 mt/ha) yield were observed in T2 (Syzygium cumini) and T3 (Psidium guajava) treatments, respectively (Table 5$)$. The yield $(10.00 \mathrm{mt} / \mathrm{ha})$ of T10 ( $\mathrm{LaW}$ sonia inermis) treatment was also promising. However, all the botanical extracts increased the yield notably. The highest (71.29\%) increment of yield was observed in T2 and lowest (11.88\%) in T3 treatment over T0 (untreated control). The rest of the botanical extracts increased the yield between $14.85 \%-48.51 \%$.

\section{Discussion}

Late blight disease of potato is the main threat to potato production. In favorable condition the disease spreads in the field very rapidly and destroys the whole field within very short time and consequently the yield deceases extremely. Although the chemical fungicides are the major tolls to fight against the late blight

Table 4. Efficacy of plant extracts on disease severity (\%) of potato late blight disease at different days after sowing (DAS).

\begin{tabular}{ccccc}
\hline Treatment & \% Severity at DAS 50 & \% Severity at DAS 58 & \% Severity at DAS 66 \% Severity at DAS 73 \\
\hline T0-Untreated control (Water) & $0.10 \pm 0.06 \mathrm{a}$ & $17.83 \pm 1.92 \mathrm{a}$ & $65.17 \pm 4.21 \mathrm{a}$ & $100.00 \pm 0.00$ \\
T1-Positive control (Fungicide) & $0.00 \pm 0.00 \mathrm{~b}$ & $0.00 \pm 0.00 \mathrm{~d}$ & $0.73 \pm 0.03 \mathrm{f}$ & $5.10 \pm 0.55 \mathrm{c}$ \\
T2-Syzygium cumini & $0.00 \pm 0.00 \mathrm{~b}$ & $0.03 \pm 0.03 \mathrm{~d}$ & $21.50 \pm 0.00 \mathrm{e}$ & $72.67 \pm 4.09 \mathrm{~b}$ \\
T3-Psidium guajava & $0.03 \pm 0.03 \mathrm{~b}$ & $2.30 \pm 0.15 \mathrm{bc}$ & $45.83 \pm 0.83 \mathrm{bc}$ & $100.00 \pm 0.00 \mathrm{a}$ \\
T4-Eucalyptus globusus & $0.00 \pm 0.00 \mathrm{~b}$ & $2.53 \pm 0.84 \mathrm{~b}$ & $50.83 \pm 3.33 \mathrm{~b}$ & $100.00 \pm 0.00 \mathrm{a}$ \\
T5-Allium sativum & $0.00 \pm 0.00 \mathrm{~b}$ & $1.03 \pm 0.44 \mathrm{bcd}$ & $41.67 \pm 0.833 \mathrm{c}$ & $99.17 \pm 0.17 \mathrm{a}$ \\
T6- Terminalia bellirica & $0.00 \pm 0.00 \mathrm{~b}$ & $0.63 \pm 0.89 \mathrm{bcd}$ & $45.67 \pm 1.59 \mathrm{bc}$ & $100.00 \pm 0.00 \mathrm{a}$ \\
T7- Terminalia chebula & $0.00 \pm 0.00 \mathrm{~b}$ & $0.53 \pm 0.29 \mathrm{bcd}$ & $30.50 \pm 3.55 \mathrm{~d}$ & $98.00 \pm 0.76 \mathrm{a}$ \\
T8-Piper nigrum & $0.00 \pm 0.00 \mathrm{~b}$ & $0.47 \pm 0.19 \mathrm{~cd}$ & $34.67 \pm 2.03 \mathrm{~d}$ & $100.00 \pm 0.00 \mathrm{a}$ \\
T9-Syzygium aromaticum & $0.00 \pm 0.00 \mathrm{~b}$ & $0.20 \pm 0.15 \mathrm{~d}$ & $31.50 \pm 1.50 \mathrm{~d}$ & $98.67 \pm 0.33 \mathrm{a}$ \\
T10-Lawsonia inermis & $0.00 \pm 0.00 \mathrm{~b}$ & $0.10 \pm 0.00 \mathrm{~d}$ & $35.00 \pm 1.44 \mathrm{~d}$ & $98.33 \pm 0.67 \mathrm{a}$ \\
T11-Carica papaya & $0.00 \pm 0.00 \mathrm{~b}$ & $0.20 \pm 0.06 \mathrm{~d}$ & $32.17 \pm 2.80 \mathrm{~d}$ & $100.00 \pm 0.00 \mathrm{a}$ \\
\hline
\end{tabular}


Table 5. Yield per plot and \% Yield increment over control.

\begin{tabular}{cccc}
\hline Treatment & Yield (kg/plot) & Yield (mt/ ha) & Yield increase over control (\%) \\
\hline T0-Untreated control (Water) & $1.01 \pm 0.06 \mathrm{~d}$ & 6.73 & +291.23 \\
T1-Positive control (Fungicide) & $3.95 \pm 0.08 \mathrm{a}$ & 26.33 & +71.29 \\
T2-Syzygium cumini & $1.73 \pm 0.06 \mathrm{~b}$ & 7.53 & +11.88 \\
T3-Psidium guajava & $1.13 \pm 0.05 \mathrm{~cd}$ & 7.73 & +14.85 \\
T4-Eucalyptus globusus & $1.16 \pm 0.14 \mathrm{~cd}$ & 9.27 & +37.62 \\
T5- Allium sativum & $1.39 \pm 0.14 \mathrm{bcd}$ & 8.87 & +31.68 \\
T6- Terminalia bellirica & $1.33 \pm 0.09 \mathrm{bcd}$ & 9.00 & +33.66 \\
T7- Terminalia chebula & $1.35 \pm 0.20 \mathrm{bcd}$ & 9.20 & +36.63 \\
T8-Piper nigrum & $1.38 \pm 0.06 \mathrm{bcd}$ & 9.03 & +34.65 \\
T9-Syzyium aromaticum & $1.36 \pm 0.19 \mathrm{bcd}$ & 10.00 & +48.51 \\
T10-Lawsonia inermis & $1.50 \pm 0.23 \mathrm{bc}$ & 9.14 & +35.64 \\
T11-Carica papaya & $1.37 \pm 0.05 \mathrm{bcd}$ & &
\end{tabular}

of potato till the date, the development of resistance to chemical fungicides specially metalaxyl resistance by some strains of $P$. infestans reported in different parts of the world. Environmental pollution by chemical fungicides is a matter of concern now. Therefore, the necessity of eco-friendly natural products is increasing day by day. Natural compounds of plants are very good alternative because of their biodegradability and low toxicity to environment and human. Plants have different mechanisms to fight against fungal attack. They fight against fungal attack by using chemical defense systems through producing secondary metabolites like phenols, flavanoids, quinones, terpenes, tannins, alkaloids, lectins, polypeptides, saponins, sterols, etc. [22]. Plant extracts with rich in secondary metabolites can kill the fungus, disrupt the fungal cell membrane and inactivate various enzymes as well as metabolic processes of pathogen [23].

Efficacy of plant extracts against $P$. infestans at in vitro and under field conditions was assessed by many researchers named as Cao [24], Khair [11], Majeed [25] and Subhani [26] for last few decades. But the field assessment of plant extracts against late blight of potato is still limited. Leaf extracts of Podophyllum hexandrum were found more effective in minimizing the incidence of late blight disease of potato and produced better tuber yield under natural field conditions [25]. The extract of Populus nigra (both 5\% and 10\%) reduced late blight's severity on potato leaves under field conditions and proved more effective than conventionally used fungicides [27]. Jabeen and Javaid [28] observed that 5\% aqueous extracts of $S$. cumini leaf reduce the growth of chickpea blight disease pathogen Ascochyta rabiei upto 64\%. Khan et al. [29] found methanolic leaf extract of S. cumini effective against damping off disease pathogen Rhizoctonia solani. S. cumini leaf extract showed significant antifungal activity against Aspergillus species responsible for seed bio-deterioration during storage [30].

The present study evaluated the efficacy of ten Bangladeshi botanicals against 
late blight disease of potato at field level. This study observed that Syzygium cumini leaves extract show best efficacy in terms of reduction of disease incidence and severity of late blight. The increment of yield of potato of this treatment was also higher compare to untreated control. The reduction of disease incidence and severity of other botanicals were found low to moderate over untreated control up to 66 DAS. Khair and Haggag found that $2.5 \%$ aqueous extract of garlic reduces the late blight severity by $54.2 \%$ [11] that agrees with findings of 66 DAS of the present study. Findings of Subhani [26] showed that garlic extract reduces the intensity by $44.4 \%$ and $47 \%$, respectively, which agrees with the present findings. Cao [27] found that Horitoki (Terminalia chebula) reduces infection on detached leaves up to $99.4 \%$. These results also support our findings on Horitoki at field conditions. Khair [11] and Subhani [26] found that eucalyptus reduces the disease severity to $34.3 \%$ and $28.35 \%$ under field conditions, which is almost similar to the findings of present study.

\section{Conclusions}

The present study revealed that aqueous extracts of all botanicals except Psidium guajava and Eucalyptus globusus controlled the late blight incidence and severity effectively up to 66 DAS though the intensity of late blight disease was high. Out of ten botanicals, Syzygium cumini leaves extract was found very effective in controlling the late blight disease incidence and severity and increased the potato yield by $71.29 \%$ compare to untreated control. These findings suggest that in early to medium stage (58 - 66 DAS), potato grower can use the botanical extracts to control the late blight disease in field. Therefore, the present study is a great step towards the exploration of an eco-friendly botanical fungicide like $S y$ zygium cumini extract as an alternative of conventional toxic chemical fungicides.

Considering the low cost option of aqueous extracts, organic solvent extraction process was not done during this study. Chemical solvent extraction with methanol, ethanol, chloroform and n-hexane is underway for future study.

\section{Conflicts of Interest}

The authors declare no conflicts of interest regarding the publication of this paper.

\section{References}

[1] CIPOTATO (2021) Potato Facts and Figures. https://cipotato.org/potato/potato-facts-and-figures/

[2] Singha, U. and Maezawa, S. (2019) Production, Marketing System, Storage and Future Aspect of Potato in Bangladesh. Reviews in Agricultural Science, 7, 29-40.

[3] King, J.C. and Slavin, J.L. (2013) White Potatoes, Human Health, and Dietary Guidance. Advances in Nutrition, 4, 393-401.

[4] Abouzied, M.M. and Reddy, C.A. (1986) Direct Fermentation of Potato Starch to Ethanol by Cocultures of Aspergillus niger and Saccharomyces cerevisiae. Applied 
and Environmental Microbiology, 52, 1055-1059.

[5] Azad, A.K., Yesmin, N., Sarker, S.K., Sattar, A. and Karim, R. (2014) Optimum Conditions for Bioethanol Production from Potato of Bangladesh. Advances in Bioscience and Biotechnology, 5, 501-507. https://doi.org/10.4236/abb.2014.56060

[6] FAOSTAT (2019). http://www.fao.org/faostat/en/\#rankings/commodities_by_country

[7] CIP (1984) Potatoes for the Developing World, Lima Peru. 66 p.

[8] Agrios, G.N. (2005) Plant Pathology. 5th Edition, Academic Press, London.

[9] Chycoski, C.I. and Punja, Z.K. (1996) Characteristics of Populations of Phytophthora infestans from Potato in British Columbia and Other Regions of Canada during 1993 to 1995. Plant Disease, 80, 579-589. https://doi.org/10.1094/PD-80-0579

[10] Fry, W.E. and Goodwin, S.B. (1997) Resurgence of the Irish Potato Famine Fungus. BioScience, 47, 363-371.

[11] Khair, A.E. and Haggag, W.M. (2007) Application of Some Egyptian Medicinal Plant Extracts against Potato Late and Early Blights. Research Journal of Agriculture and Biological Sciences, 3, 166-175.

[12] Dey, T.K., Hossain, M., Kadian, M.S., Hossain, S., Bonierbale, M. and Mahmud, A.A. (2010) Prevalence, Epidemiology and Management of Potato Late Blight in Bangladesh. Potato Journal, 37, 99-102.

[13] Laxmishree, C. and Nandita, S. (2017) Botanical Pesticides-A Major Alternative to Chemical Pesticides: A Review. International Journal Life Sciences, 5, 722-729.

[14] Wedge, D.E. and Smith, B.J. (2006) Discovery and Evaluation of Natural ProductsBased Fungicides for Disease Control of Small Fruits. In: Inderjit and Mukerji, K., Eds., Allelochemicals. Biological Control of Plant Pathogens and Diseases, Springer, Dordrecht, 1-14. https://doi.org/10.1007/1-4020-4447-X_1

[15] Yoon, M.Y., Cha, B. and Kim, J.C. (2013) Recent Trends in Studies on Botanical Fungicides in Agriculture. The Plant Pathology Journal, 29, 1-9.

https://doi.org/10.5423/PPJ.RW.05.2012.0072

[16] Knight, S.C., Anthony, V.M., Brady, A.M., Greenland, A.J., Heaney, S.P., Murray, D.C., Powell, K.A., Schulz, M.A., Spinks, C.A., Worthington, P.A. and Youle, D. (1997) Rationale and Perspectives on the Development of Fungicides. Annual Review of Phytopathology, 35, 349-372.

https://doi.org/10.1146/annurev.phyto.35.1.349

[17] Dwivedi, S.K. and Singh, K.P. (1999) Fungitoxicity of Some Higher Plant Products against Macrophomina phaseolina (Tassi) Goid. Flavour and Fragrance Journal, 13, 397-399.

https://doi.org/10.1002/(SICI)1099-1026(199811/12)13:6\%3C397::AID-FFJ762\%3E3 .0.CO;2-L

[18] Azad, A.K., Sardar, A., Yesmin, N., Rahman, M. and Islam, S. (2013) Eco-Friendly Pest Control in Cucumber (Cucumis sativa L.) Field with Botanical Pesticides. Natural Resources, 4, 404-419. https://doi.org/10.4236/nr.2013.45050

[19] Sajid, M.N. and Shah, S.I.H. (2018) Effectiveness of Some Fungicides against Late Blight of Potato Caused by Phytophthora infestans. Plant Protection, 2, 31-34.

[20] James, W.C. (1971) An Illustrated Series of Assessment Keys for Plant Diseases, their Preparation and Usage. Canadian Plant Disease Survey, 51, 39-65.

[21] Ray, P.K., Singh, H.K., Chaudhary, A. and Verma, R.B. (2018) Effect of Certain Fungicides and Botanicals against Late Blight of Potato (Phytophthora infestans). Current Journal of Applied Science and Technology, 31, 1-5. 
https://doi.org/10.9734/CJAST/2018/45896

[22] Martinez, J.A. (2012) Natural Fungicides Obtained from Plants. In: Dhanasekaran, D., Thajuddin, N. and Panneerselvam, A., Eds., Fungicides for Plant and Animal Diseases, IntechOpen, London, 3-28

[23] Aye, S.S. and Matsumoto, M. (2011) Effect of Some Plant Extracts on Rhizoctonia spp. and Sclerotium hydrophilum. Journal of Medicinal Plant Research, 5, 3751-3757.

[24] Cao, K.Q. and Bruggen, A.H.C.V. (2001) Inhibitory Efficacy of Several Plant Extracts and Plant Products on Phytophthora infestans. Journal of Agricultural University of Hebei, 2, 90-96.

[25] Majeed, A., Ahmad, H., Chaudhry, Z., Jan, G., Alam, J. and Muhammad, Z. (2011) Assessment of Leaf Extracts of Three Medicinal Plants against Late Blight of Potato in Kaghan Valley, Pakistan. Journal of Agricultural Technology, 7, 1155-1161.

[26] Subhani, M.N., Sahi, S.T., Hussain, S., Munir, N., Abbas, W. and Bilal, M. (2014) Evaluation of Antifungal Effect of Different Plant Extracts for the Management of Late Blight of Potato Caused by Phytophthora infestans (Mont.) de Bary. Journal of Biologically Active Products from Nature, 4, 125-135.

https://doi.org/10.1080/22311866.2014.886961

[27] Cao, K.Q., Wang, S.T., Forrer, H.R. and Fried, P.M. (2004) Inhibitory Effects of Chinese Medicinal Plants against Phytophthora infestans on Potatoes. Proceedings of Regional Workshop on Potato Late Blight for East and Southeast Asia and Pacific, Yezin, 24-25 August 2004, 45-53.

[28] Jabeen, K. and Javaid, A. (2010) Antifungal Activity of Syzygium cumini against Ascochyta rabiei-The Cause of Chickpea Blight. Natural Product Research, 24, 11581167. https://doi.org/10.1080/14786410902941154

[29] Khan, A., Jabeen, K. and Iqbal, S. (2016) Antifungal Activity of Syzygium cumini L. against Rhizoctonia solani. Pure and Applied Biology, 5, 193-199. https://doi.org/10.19045/bspab.2016.50025

[30] Satish, S., Mohana, D.C., Ranhavendra, M.P. and Raveesha, K.A. (2007) Antifungal Activity of Some Plant Extracts against Important Seed Borne Pathogens of Aspergillus sp. Journal of Agricultural Technology, 3, 109-119. 